\title{
ROVAC の本邦産ヨークシヤ種に対する予備試験
}

\author{
杉村克治* 佐藤卯三郎** 成田亮一**
}

\section{1.は し が き}

KOPROWSKI, JAMEs 及び $\operatorname{Cox}^{1}$ ) が豚コレラ病毒の家本 化に成功し，家鬼化病毒による豚コレラ生毒ワクチンが 1950年以来アメリカで新しく登場し豚コレラ防疫の一新 武器として世界の注視を集めるようになっだ.本編はわ れわれが 1952 年 10 月に創めて行った家农化毒ワクチン (ROVAC, Lederle Laboratories Division)の本邦産 ヨークシャ瓶に対する予倩的試験の概況で, その後展鼠 した Koprowski 株に対する検討のための示唆を与えた ものとして注目に価する. 以下その大要を述べる.

\section{2. 行っ実験の方法}

供試ROVAC は Serial No. 6283 158A で型のよう 注㴬材料を調䎇し, 直ち試験豚 (埼玉県秩父産, 体重 $-40 \sim 50 \mathrm{~kg}$ の健康なヨークシャ覣で豚コレラの予防注射 を行わないもの）、10頭分，5磌分，1頭分(規定量)， $1 / 2$ 頭分， $1 / 5$ 頭分支び $1 / 20$ 頭分をそれぞれ内股部筋肉 内に注射し, 体温, 一般臨床, 血液検查を行ってそ の反応の程度を検査し，28日後に病毒攻慗を行って 免疫蒦得の状態を検査した。

\section{3. その 成 績}

その1; 反応の程度 10 頭分を注射した 410 号豚 は最高体温 $40.4^{\circ} \mathrm{C}$ 示し, $40^{\circ} \mathrm{C}$ 前後の発熱を和特 むね14日間管留したが，一般臨床上には著変を認め ず，数日の元気沈衰及び食欲の減退を認めたにすぎ なかった，次に 5 頭分を注射した 407 号豚は，いわ ゆる注射反忘の後に潮次体温の上杽を来し，8日目 には最高体温 $41^{\circ} \mathrm{C}$ を示し， $40^{\circ} \mathrm{C}$ 以上の稳留を特 括さ致 7 日間認めたが, その後 $39.5^{\circ} \mathrm{C}$ 前後の体温 を維持継繶した。一般臨床所見としては， $40^{\circ} \mathrm{C}$ 以 上の熱䝑留を認的た数日にわたり 元気沈衰, 食欲の減退が認められ た。

1 頭分規定量を注射した 408 号 闻は7 日目に最高体温 $40.6^{\circ} \mathrm{C}$ を 示し, $39.5 \sim 40.6^{\circ} \mathrm{C}$ の体温を特

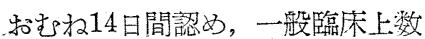
日にわたり元気㴷谷食欲の減退が 認められた。

1 頭分の $1 / 2$ 量を注射した 409

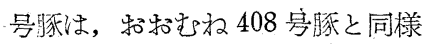
の成績を示し, 注射後 7 日目に最 高 $40.4^{\circ} \mathrm{C}$ の発㙓を認めたが，そ

\footnotetext{
* 元畜産局薬事課，現家畜衛生 試験場 **畜産局, 薬事課
}

の後漸次平熱に回復した。

しかして $1 / 5$ 頭分を注射した 434 号豚と 1/20 磌分を 注射した 435 号豚は，注射後体温及び臨床上なんらの変 化多認められなかった。

以上のように規定の 1 頭分，またはそれ以上の注射を 行うと必ず反応を呈し発病を示すが, 蓺型及び一般臨床

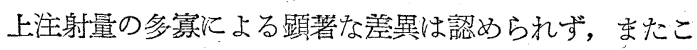
れらの試験豚で死の転帰をとったものはなかった。しか 乙耐過回復時の体温の正常状態への復帰は比較的緩慢で $39.5^{\circ} \mathrm{C}$ 前後の体温を相当長時日にわたり継綂すること が認められた。(附図参照)

その 2 ; 獲得しれ免疫の状態 10 頭分を注射した 410 号豚に対して 28 日後A L D 株の100万ML Dで攻撃し, 免疫獲得の状態を検査したところ, 軽度の体温の動摇と 数日の元笑沈衰を認めたが完全に酎過した。をた 5 磌分 を注射した 407 号豚は宫崎株の10万ML Dで攻撃したと

\begin{tabular}{|c|c|c|c|c|c|c|c|c|c|c|}
\hline & \multicolumn{2}{|c|}{ 試 } & & 繶 & & \multicolumn{2}{|c|}{ 表 } & \multicolumn{3}{|c|}{ Semolo. $6283-158 A$} \\
\hline & 体寒 & & ROVAC & 注 & 安全試 & 呀 & 埭: & 力传試 & & \\
\hline & $(k 8)$ & 泩 & 注射量 & 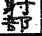 & 反 應 & 結果 & 案 & 反 髉 & 结果 & 傮存 \\
\hline 410 & 47 & $\$$ & 10 倍量. $20 \mathrm{cc}$ & & 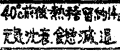 & + & ALD㧣 & 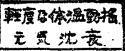 & 而过题 & 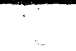 \\
\hline 2407 & 47 & to & 5 借量 $10_{t c}$ & & 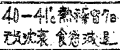 & + & 102 & $\sqrt{5} \quad L$ & 碚透 & \\
\hline 3408 & 48 & $\hat{f}$ & 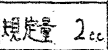 & 致 & 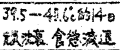 & $H$ & A & 56 & & \\
\hline 409 & 47 & t & $1 / 2 \frac{\dot{g}}{T^{2}} I_{c c}$ & 肉 & 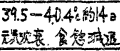 & $H$ & $\dot{L}$ & $\sqrt{3} 6$ & & \\
\hline 434 & 48 & 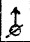 & $1 / 5$ 量 $0.4 \mathrm{cc}$ & 内 & 16 & 一 & $\frac{1 \pi}{\pi}$ & 玨症.98目死。 & 警死 & 憕コレ\%。 \\
\hline 6) 435 & 46 & 9 & $1 / 20$ 量 0.1 c.e & & & - & $\stackrel{M}{M}$ & 深证 20 日死 & 警死 & 豚コレう. \\
\hline $7 / 437$ & 40 & 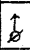 & 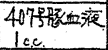 & $\frac{7}{5}$ & $39.5-40^{\circ} \mathrm{C}$ 的 $10_{\theta}^{\circ}$ & + & 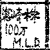 & t & 标遥 & \\
\hline 8287 & 45 & $\delta$ & & & & & 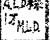 & 证噔 140 死 & 都死 & 限こレร. \\
\hline 368 & 50 & 우 & & & & & 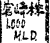 & 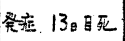 & 繁死 & 咸こレラ. \\
\hline
\end{tabular}

第1図 ROVAC 10倍淂 (2006) 注射豚

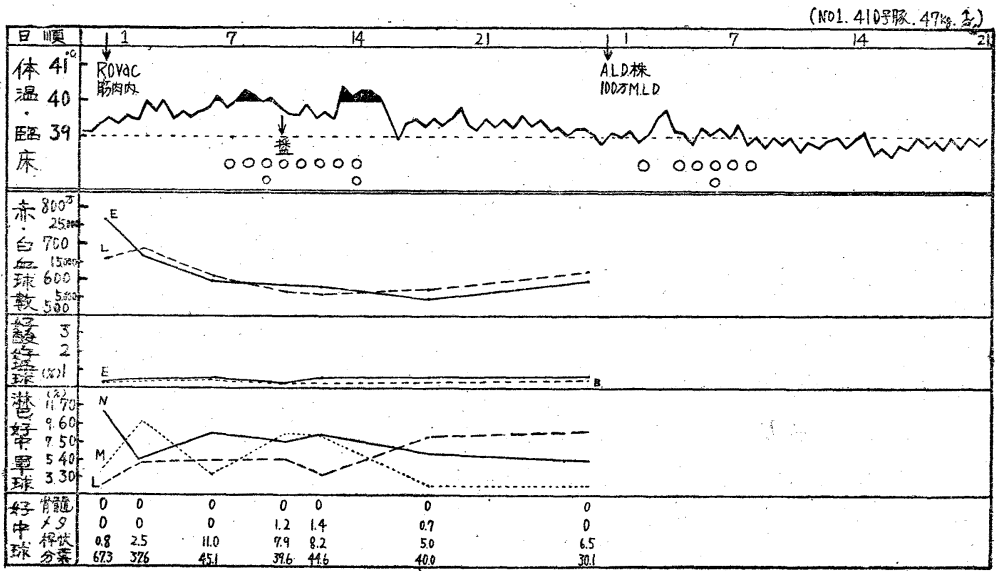


ころ, 体温乙文び臨床上なんらの変化を認めずに耐過し た.

1 頭分及び $1 / 2$ 量を注射した 408 号文び 409 号豚はA LD株の 1 万MLDで攻撃したが 408 号豚はなんらの異 常もなく，409 号豚は軽度の体温の動摇を見たが完全に
第 2 図 ROVAC 5咅量 (10ce) 注射豚

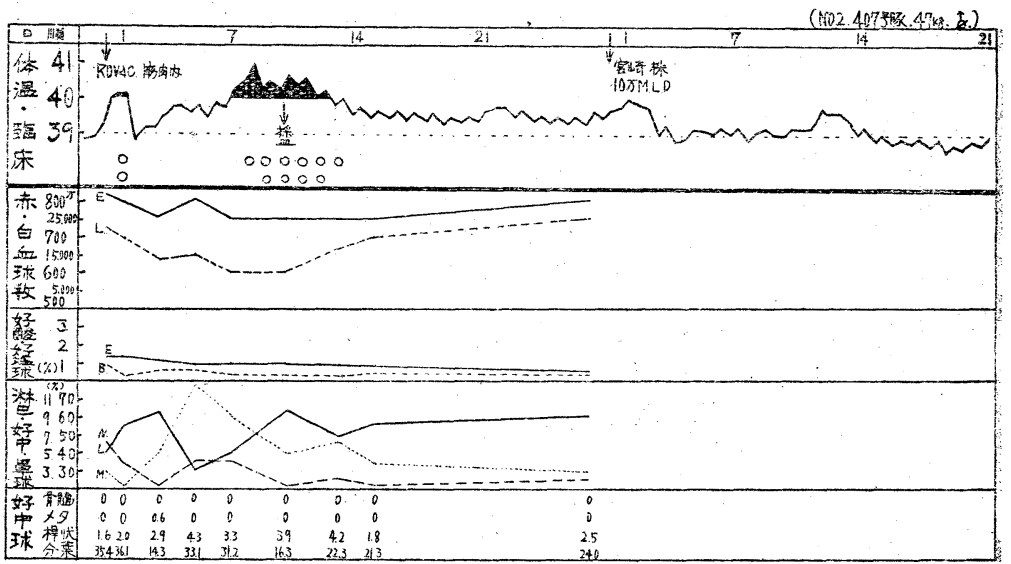

第 3 図 ROVAC 規定量 $(2.0 \mathrm{cc})$ 注射豚

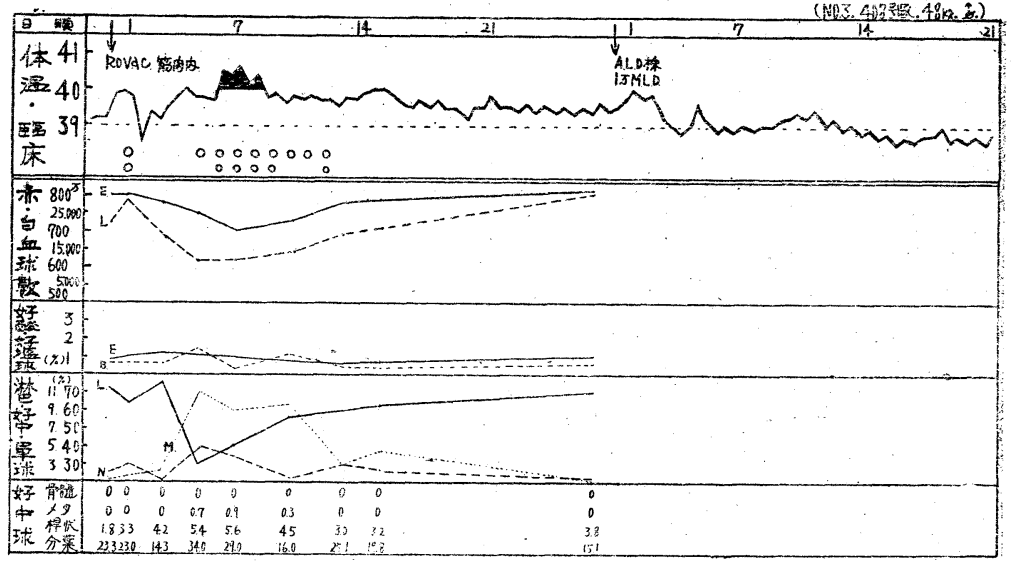

第 4 図 ROVAC $1 / 2$ 量 $(1.0 \mathrm{cc})$ 注射豚

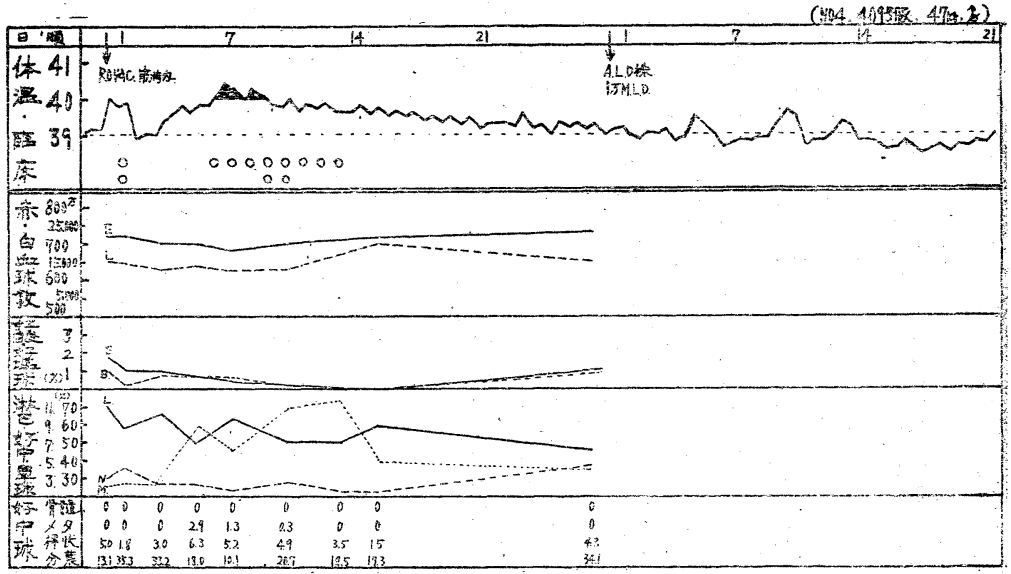




\section{4. 之 め}

本邦産ヨークシャ種の豚汅 ROVACを規定量または その 5〜10倍を注射すると，いずれる中等度の発熱と一 般臨床上元父沈衰, 食欲減退などが認められる。このこ

第 5 図 ROVAC $1 / 5$ 量 $(0.4 \mathrm{cc})$ 注射豚
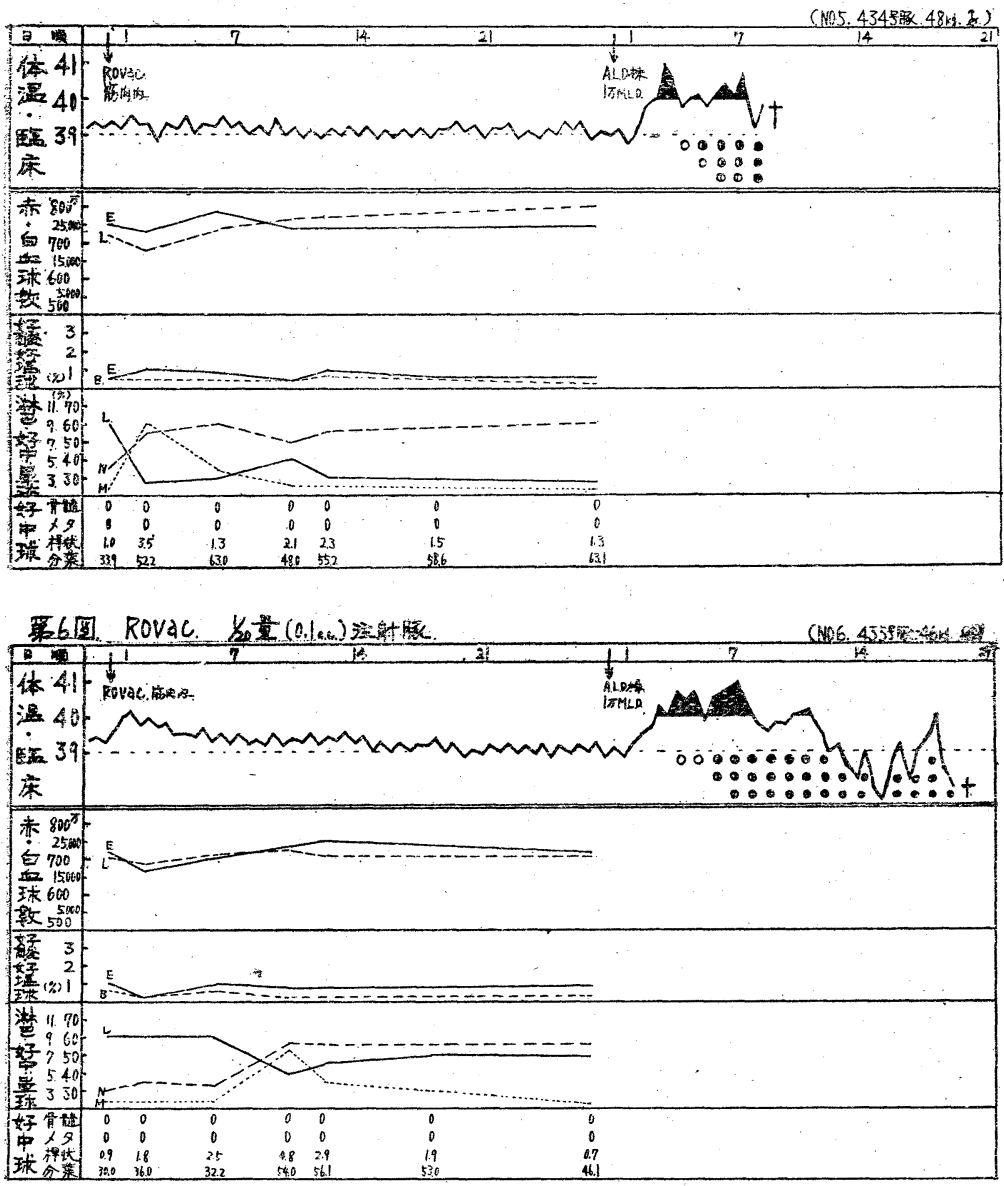

第 7 図 発熱時血液注射豚

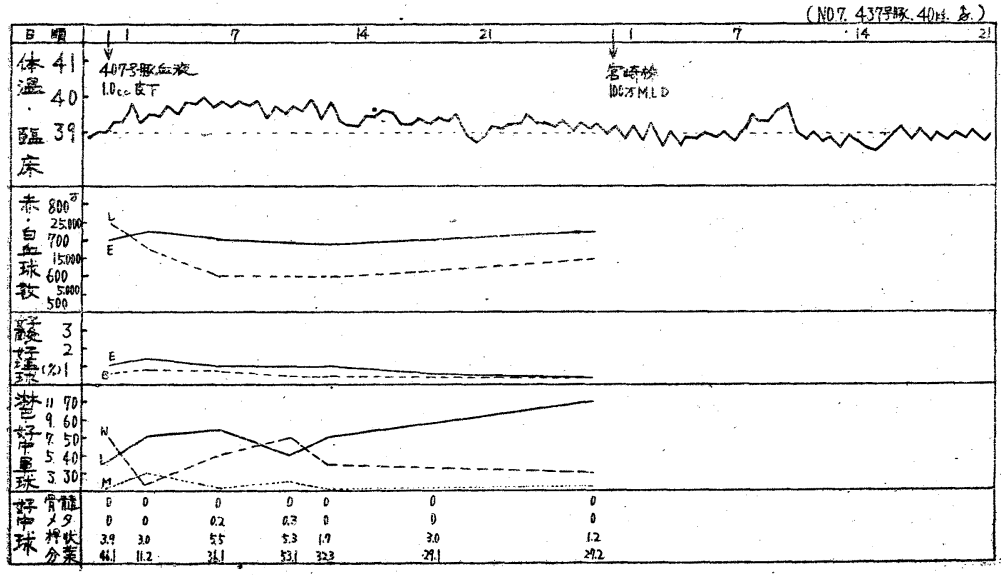

とは変異病毒の体内增殖による発病と見做すが規定量注

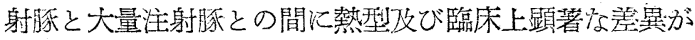
認められず，いずれも完全に洏過し，死亡したものはな かった。またこれらの豚は極めて強固な免疫を獲得し た。

$1 / 5$ さたは $1 / 20$ 量などの規定量 以下の微量注射豚では注射後なん らの異掌を認められなかったが1 万倍MLDの病毒攻撃に耐遄する 免疫を認めることはできなかっ た。

以上は予埆試験の概況であって この変買病毒の毒性, 体内增殖 性，病毒排泄などに関し㯖々の問 題を提起寸るものである。しかし てこれらの諸点は次編に执いて逐 次論皮したい。

稿を終るに当りこの実験遂行の ため配慮を受けを薬事課長星修三 博士，供試 ROVAC を提供せら れたる Lederle Laboratories Division, 同東京支社スコット氏 䏠びに武田薬品工業株式会社に深 謝する。

$$
\text { 文献 }
$$

1) KOPROWSKI H, JAMES R. COX R. : Proc. Soc. Exp. Biol. Med., $1946,63,178$,

\section{牛の顆粒性窗炎不妊泟}

顆粒性胵焱にかかると腔の粘膜 や牡の包皮や龟頭部なぞに小さな 結節ができる。若い牝犢が括かさ れた場合, 最も䅹状が激しく,つ いには不妊症となる。重症では潮 紅性結節がしばしば融合し，炎症 を発し, 膿性粘液を伴う、俥症で は炎症や膿性粘液なく少数の結節 が存在するだけである.1951年か ら1952年にわたる9 カ月閽にケン タッキー洲て 4,616 頭の牝牛を検 查したところ $47 \%$ 軽症， $7 \%$ に 重症罹患を認めた。そして症状の 軽重程度に伴い，3〜10\%が妊娠 能力が減退しているととを認め, 特に重症例の受胎率法58.1\%であ った, (E. C. Troutman:J. A. V.M.A, 124, 924, 1954)

日獣会誌 7 (1954) 